\title{
ブドウ葉片浸漬法によるチャノキイロアザミウマに対する 合成ピレスロイド剂の殺虫効果
}

\author{
柴尾 学・田中 寛 \\ （大阪府環境農林水産総合研究所）
}

\begin{abstract}
チャノキイロアザミウマScirtothrips dorsalis Hood は ブドウ, カンキツ, カキなど果樹を加害し，果実の商品 価值を低下させる害虫である5)。現在，ブドウでは本種 に対して比較的多くの登録薬剤がある。しかし，2003年 に大阪府羽曳野市の環境農林水産総合研究所内露地ブド ウにおいて本種に対して登録のある合成ピレスロイド系 のペルメトリン剂を散布したにもかかわらず十分な防除 効果が得られない事例が認められた ${ }^{4)}$ 。そこで, 著者ら は同圃場で採集した本種個体群について合成ピレスロイ ド剤の殺虫効果をブドウ葉片浸漬法により調査したので 報告する。
\end{abstract}

\section{材料および方法}

試験は2004年および2005年に環境農林水産総合研究所 内の人工気象器 $\left(25^{\circ} \mathrm{C}, 16\right.$ 時間日長）において行った。 供試虫は試験当日, 同所内の露地ブドウ (品種 : デラウェ ア, 32年生, 無農薬栽培)から採集した 2 齢幼虫を用いた。

試験Ｉ：2004年 7 月 1 日，ペルメトリン剂を所定濃度 に希釈した。同所内のガラス室で栽培したポット栽培ブ ドウ葉（品種 : デラウェア, 農薬無散布）を直径 $8 \mathrm{~cm}$ の円盤形に切り抜いてリーフディスクを作成し，希勫溶 液に 1 分間浸漬した後, ろ紙上で風乾した。直径 $9 \mathrm{~cm}$ のプラスチックシャーレに水を含ませた脱脂綿を敷き， その上に上記リーフディスクを葉表を上にして置いた 後, $2 \times 2 \mathrm{~cm}$ の穴を均等に 4 か所開けた直径 $8 \mathrm{~cm}$ の円 盤形のろ紙でリーフディスクを上から覆い, 十分量の水 でろ紙を浸した。無処理ではリーフディスクを水に浸漬 し, 同様に処理した。供試虫はろ紙に開けた穴枠内のリー フディスク上に接種し，シャーレの蓋をしたした後，人 工気象器に置いた。 1 区10～12個体の 4 反復とした。調 査は接種 1 日後および 4 日後に実体顕微鏡下でろ紙に開 けた穴枠内のリーフディスク上の供試虫を生存虫（筆先 でつついて動くもの）と死亡虫（筆先でつついて動かな いもの）の別に，また，ろ紙に付着した供試虫を付着虫
として計数した。付着虫は薬剂の殺虫効果による生死の 判別ができないため, 供試個体から除き, 死亡率を算出 した。

試験 II : 2005年 7 月15日に第 2 表に示した薬剤を供試 し, 試験 I と同様に処理した。調査は接種 1 日後に試験 I と同様に行った。

各種薬剤の殺虫効果は補正死亡率により判断し, $90 \%$ 以上で高い，70\%以上で認められる，70\%未満で低いと した。

\section{結果および考察}

試験 I : 試験 I における死亡率を第 1 表に示した。無 処理では接種 1 日後および 4 日後の死亡率がそれぞれ $0 \%$ そ \%であった。ペルメトリン剂の1,000倍液では 接種 4 日後の補正死亡率が $81 \%$ で殺虫効果は認められた が, 接種 1 日後の死亡率は65\%で殺虫効果は低かった。 また, ペルメトリン剂の2,000～8,000倍液ではいずれも 死亡率が70\%未満で殺虫効果は低かった。2003年 7 月に 同圃場で採集した本種 2 齢幼虫に対して同様の方法によ りペルメトリン剂の殺虫効果を調査したところ, 接種 1 日後の死亡率は1,000倍液では74\%，2,000倍液では72\% で殺虫効果が認められたがその程度は低く, 4,000～8,000 倍液では70\%未満で殺虫効果は低く, 本試験の結果とほ ぼ一致していた ${ }^{4)}$ 。ペルメトリン $20 \%$ 水和剂はブドウで は本種に対して実用濃度2,000〜4,000倍で農薬登録され ている。したがって, 本剂を実用濃度で散布しても十分 な防除効果が得られない可能性が示唆され, 本種はペル メトリン剂に対して抵抗性を発達させたと考えられる。 なお, 河合 ${ }^{1)}$ は静岡県のチャで採集した本種 1 齢幼虫の 死亡率がペルメトリン剂では47\%で低いことを報告して おり，本試験と同様の結果であった。

試験 II ：試験 II における死亡率を第 2 表に示した。無 処理の死亡率は $0 \%$ あ゙あった接種 1 日後の死亡率はア クリナトリン剂およびシフルトリン剂では100\%で殺虫

Manabu Shibao and Hiroshi Tanaka (Res. Inst. Environ., Agric. \& Fish., Osaka Pref. Govern.): Effect of pyrethroid insecticide on yellow tea thrips, Scirtothrips dorsalis Hood with grape leaf dipping method. 2008年 2 月 15 日受理 
第 1 表 チャノキイロアザミウマに対する薬剤殺虫効果（試験 I ）

\begin{tabular}{|c|c|c|c|c|c|c|c|c|c|c|c|}
\hline \multirow{2}{*}{ 供試薬剂（希釈倍数） } & & \multicolumn{5}{|c|}{ 接種 1 日後 } & \multicolumn{5}{|c|}{ 接種 4 日後 } \\
\hline & & 供試 & 生存 & 死亡 & 付着 & 死亡率（\%） & 供試 & 生存 & 死亡 & 付着 & 死亡率（\%） \\
\hline ペルメトリン $20 \%$ 水和剂 & $(1000)$ & 45 & 14 & 26 & 5 & 65.0 & 42 & 6 & 27 & 9 & $81.8(81.3)$ \\
\hline " & $(2000)$ & 43 & 18 & 15 & 10 & 45.5 & 42 & 15 & 14 & 13 & $48.3(46.8)$ \\
\hline " & $(4000)$ & 42 & 26 & 13 & 3 & 33.3 & 32 & 14 & 15 & 3 & $51.7(50.3)$ \\
\hline " & $(8000)$ & 43 & 33 & 6 & 4 & 15.4 & 40 & 26 & 6 & 8 & $18.8(16.4)$ \\
\hline 無処理 & & 46 & 45 & 0 & 1 & 0 & 36 & 34 & 1 & 1 & $2.9(0)$ \\
\hline
\end{tabular}

注. 供試 : 供試虫数, 生存 : 生存虫数, 死亡 : 死亡虫数, 付着 : 付着虫数

死亡率 $(\%)=100 \times$ 死亡虫数 $/($ 生存虫数 + 死亡虫数)，（）内は補正死亡率（\%)

第 2 表 チャノキイロアザミウマに対する薬剤殺虫効果（試験 II，接種 1 日後）

\begin{tabular}{|c|c|c|c|c|c|}
\hline 供試薬剤（希釈倍数） & 供試 & 生存 & 死亡 & 付着 & 死亡率（\%） \\
\hline アクリナトリン 3 \%水和剤（1000） & 42 & 0 & 25 & 17 & 100.0 \\
\hline シフルトリン 5 \% EW（2000） & 43 & 0 & 29 & 14 & 100.0 \\
\hline シペルメトリン $6 \%$ 水和剤 $(1000)$ & 43 & 5 & 19 & 19 & 79.2 \\
\hline フルバリネート $20 \%$ 水和剂 $(4000)$ & 45 & 7 & 23 & 15 & 76.7 \\
\hline ビフェントリン $2 \%$ 水和剤 $(1000)$ & 42 & 9 & 21 & 12 & 70.0 \\
\hline ペルメトリン20\%水和剂（2000） & 43 & 17 & 21 & 5 & 55.3 \\
\hline 無処理 & 42 & 40 & 0 & 2 & 0 \\
\hline
\end{tabular}

注. 凡例は第 1 表参照

効果は高く，シペルメトリン剂，フルバリネート剂およ びビフェントリン剂では70～79\%で殺虫効果が認められ たが，ペルメトリン剤では55\%で殺虫効果は低かった。 したがって，殺虫効果は合成ピレスロイド剂の種類によ り異なることが示された。大阪府のブドウでは最近まで ペルメトリン剂が本種の基幹防除薬剤として病害虫防除 指針や防除暦に採用され，同所内のブドウにおいても継 続的に散布されてきた経緯があることから，本剤の多用 が殺虫効果の低下を招いた可能性が考えられる。今後, ペルメトリン剂を除く薬剤を用いたローテーション散布 を行う必要がある。なお，本試験の結果，ペルメトリン 剂を除く他の薬剂ではろ紙に付着する付着虫数がやや多 くなる傾向が認められた。この原因として，苦悶して動 き回る個体が多かったことや忌避効果が影響している可 能性が考えられ，今後の検討が必要である。

これまで，ブドウの本種に対して登録がある殺虫剂で は，和歌山県のイヌマキで採集した本種個体群に対して 有機リン系のアセフェート剂の殺虫効果が低いこと ${ }^{2)}$,
岡山県のブドウで採集した本種個体群に対してネオニコ チノイド系のチアメトキサム剤やチアクロプリド剤など 計 6 剂の殺虫効果が低いこと年 が報告されている。これ までの試験では, 同所内の露地ブドウで採集した本種個 体群に対するアセフェート剂の殺虫効果（柴尾, 未発表） およびネオニコチノイド系のイミダクロプリド剤の殺虫 効果 ${ }^{4)}$ はいずれも高かった。今後, 周辺地域を含めてこ れらの薬剂の殺虫効果を継続的に調査する必要がある。

\section{引用文献}

1）河合 章 (1997) 植物防疫 $51: 587-589$.

2）中一晃（2005）関西病虫研報 $47: 175$.（講要）

3）佐野敏広（2007）平成18年度近畿中国四国農業研究成果情 報 : 51-52.

4）柴尾 学・江原昭三・細見彰洋 - 田中 寛（2006）応動昆 $50: 247-252$.

5）高木一夫・西野 操 - 宮原 実 -上田登四郎（1972）植物 防疫 $26: 429-438$. 